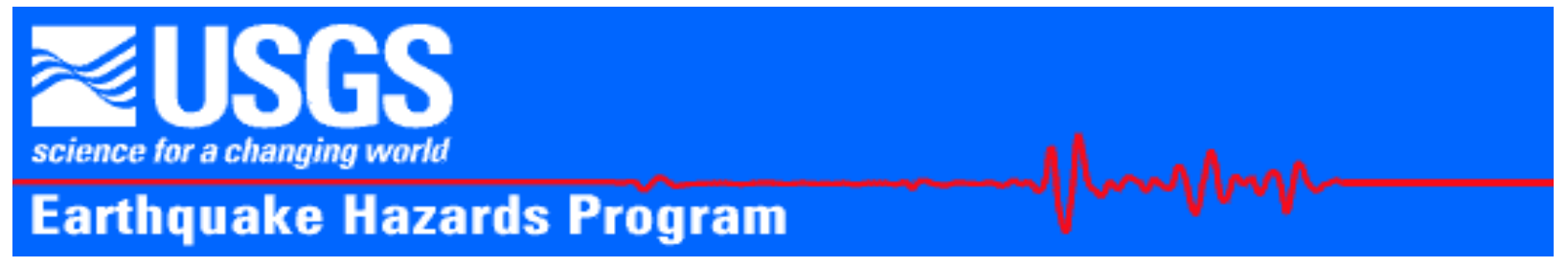

\title{
Near-Surface S-wave and P-wave Seismic Velocities of Primary Geological Formations on the Piedmont and Atlantic Coastal Plain of South Carolina, USA
}

by Jack K. Odum, Robert A. Williams, William J. Stephenson, and David M. Worley

Open-File Report 03-043

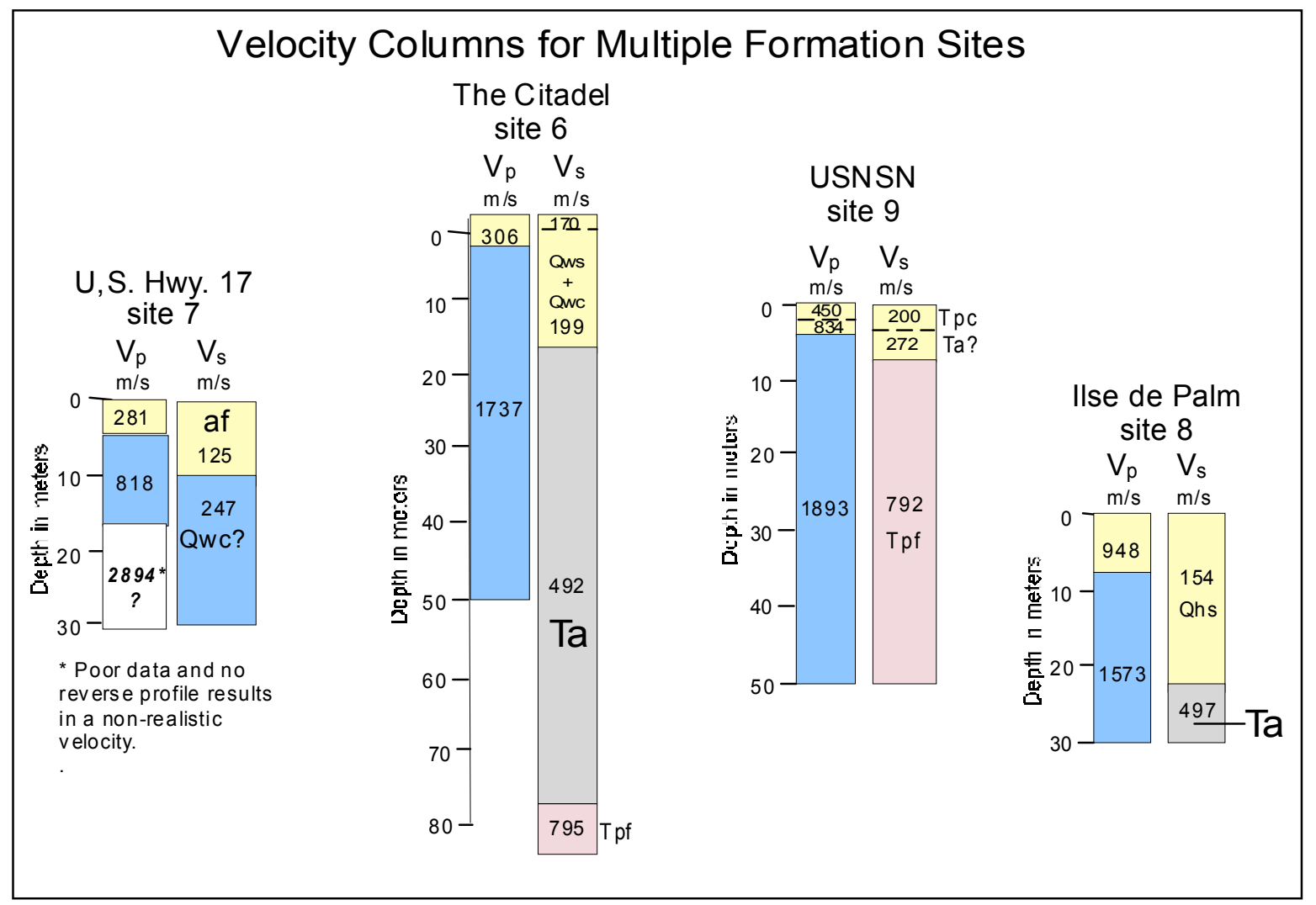

This report is preliminary and has not been reviewed for conformity with U.S. Geological Survey editorial standards or with the North American Stratigraphic Code. Any use of trade, firm, or product names is for descriptive purposes only and does not imply endorsement by the U.S. Government.

\section{U.S. DEPARTMENT OF THE INTERIOR}

\section{U.S. GEOLOGICAL SURVEY}

Golden, Colorado 


\title{
Near-Surface S-wave and P-wave Velocities of Primary Geological Formations on the Piedmont and Atlantic Coastal Plain of South Carolina, USA
}

\author{
by Jack K. Odum, Robert A. Williams, William J. Stephenson, and David M. Worley ${ }^{1}$
}

\section{INTRODUCTION}

Numerous studies over the last few decades have clearly established that shear-wave seismic velocity $\left(\mathrm{V}_{\mathrm{S}}\right)$ - in the upper 30 to $60 \mathrm{~m}$ can greatly influence the amplification and duration of earthquake ground motion observed at the surface (e.g. Bocherdt et al., 1979; Joyner et al., 1981; Seed et al., 1988). The acquisition and determination of near-surface seismic velocities are also motivated by their use in the National Earthquake Hazards Reduction Program (NEHRP) model code provisions which place a special significance on shallow $\mathrm{V}_{\mathrm{s}}$ (Building Seismic Safety Council, 1997).

Using seismic refraction/reflection profiling techniques, we acquired and determined shear-wave $\left(\mathrm{V}_{\mathrm{S}}\right)$ and compressional-wave $\left(\mathrm{V}_{\mathrm{P}}\right)$ velocities at nine locations in southeast South Carolina (specific site locations are referenced by number and plotted on Figure $1 A$ ). The sites sampled during this reconnaissance survey were selected on the premise that they were generally representative of near-surface materials associated with the primary geologic units located within the Piedmont and Atlantic Coastal Plain areas of South Carolina. Stratigraphic units sampled (Figure 1A) include: (1) Paleozoic rocks of the Carolina Slate Group at the Lake Murray spillway near Columbia, S.C., (2) the Cretaceous Tuscaloosa Formation at Ft. Jackson near Columbia, S.C., (3) the upper Cretaceous Peedee Formation at Deep Creek School, (4) the lower Tertiary Black Mingo Formation and (5) the lower Tertiary Santee Limestone. In and around Charleston, S.C. several sites that sampled the upper Tertiary Cooper Group (Ashley and Parkers Ferry Formations) and overlying Quaternary deposits include: (6) The Citadel, (9) USNSN installation site, (7) U.S. Highway 17 and (8) Pleistocene to Holocene strata at Isle of Palms north of Charleston, S.C. The U.S. Nuclear Regulatory Commission (NRC), through a joint NRC/USGS interagency agreement, provided funding for this project.

Results of this study were used to constrain shallow ( $<100$ meter) $\mathrm{V}_{\mathrm{S}}$ velocity models in a larger-scope analysis that estimated the seismic site response of Atlantic and Gulf of Mexico Coastal Plain and Mississippi Embayment regions of the southeastern United States (Mueller, 2000). In this region 0-15 kilometers of unconsolidated to weakly consolidated Cretaceous and younger sediments overlie Paleozoic bedrock. In an independent but related study, Wheeler and Cramer (2000) estimated site amplification for a proposed bridge near Charleston, S.C. Their analysis compared the amplifications that would result from various hypothetical stratigraphic columns reaching from the surface down to the metamorphic and igneous rock basement at a depth of approximately $3 \mathrm{~km}$. 


\section{GEOLOGIC SETTING AND SITE STRATIGRAPHY}

The regional coverage of this survey included portions of two distinctive geographic provinces, the Piedmont and the Coastal Plain. The Piedmont province lies between the more mountainous ( $<300$-m elevation) Blue Ridge region of western South Carolina and the "Fall Line" (represented approximately by the heavy yellow dashed line on Figure $1 A$ ); whereas the area from the "Fall Line" to the Atlantic Ocean forms the landward portion of the Coastal Plain (see cross section A-A' on Figure $1 B$ ). The physiographic feature termed the "Fall Line" marks the geographical location where folded, faulted and recrystallized basement rock (red and purple map colors on Figure $1 A$ ) are on-lapped and buried beneath the relatively undeformed sedimentary rocks (Cretaceous and Tertiary rocks (greens and oranges, respectively, on Figure 1 A)) and soils of the Coastal Plain province. The sedimentary deposits of the Coastal Plain province are typically unconsolidated, soft, and more easily eroded than the more resistant granites, gneisses and schist exposed in the Piedmont area. As defined by Cooke (1936), the boundary between the two provinces is characterized by a series of waterfalls and rapids where streams flowing off of the resistant Piedmont rocks cut deeper valleys into the softer Coastal Plain sediments (whence the term "Fall Line"). The basement rock surface underlying the Piedmont region and beneath the Coastal Plain sedimentary strata is a weathered, dissected and gently undulating peneplain (see Figure $1 B$ cross-section A-A').

The Coastal Plain province extends from the Atlantic Ocean inland for a distance of 190 to $240 \mathrm{~km}$ where it thins and disappears in the vicinity of "Fall Line" at an elevation of approximately $100 \mathrm{~m}$. This province consists of a seaward-thickening wedge of relatively undeformed and predominantly weakly-lithified to unconsolidated sedimentary units that range in age from Upper Cretaceous to Holocene (90 ma to less than $10 \mathrm{ka})$. In the vicinity of Charleston, S.C., these units are approximately $1.2 \mathrm{~km}$ thick (Bonini and Woollard, 1960). For a more in-depth discussion of the pre-Cretaceous (Jurassic, Triassic and basement complex rocks) that underlie the Charleston, S.C. area (none of which are exposed and therefore not sampled during this survey), the reader is referred to Wheeler and Cramer (2000).

Coastal Plain sedimentary units relevant to this study (those that are exposed at or near the surface) comprise a sequence of 12 formations (and/or groups) that unconformably overly basement rock. The oldest units (upper Cretaceous) are exposed to the west within the Piedmont region and successively younger units are found exposed eastward with Holocene units occurring in the coastal regions (see Figures $1 A$ and $B$, geologic map and cross-section). Figure $1 C$ presents a generalized stratigraphic column for the study area (modified from Cooke, 1936). On this figure, formations and/or groups highlighted in yellow represent stratigraphic units from which P- and S-wave velocities were obtained. Listed in the appendix are generalized descriptions of surveyed units, referenced to the site location numbers on Figure $1 \mathrm{~A}$.

\section{SEISMIC DATA ACQUISITION}

Shear-wave (S) data were recorded using a linear array of 30 to $60,4.5-\mathrm{Hz}$ horizontalcomponent geophones spaced 1.5- or 5-m apart. The geophones are single component and oriented perpendicular to the profile direction. The $S$-wave seismic source consisted of a wooden timber with steel caps placed on pavement or soil beneath the wheels of the vehicle at right angles to the direction of the profile. Reversed polarity seismic energy was produced by striking opposite ends of the timber with a $4-\mathrm{kg}$ sledgehammer. A set of reversed seismic $S$ wave profiles ranging in length from 87 to $177 \mathrm{~m}$ was collected at each site. The $S$-wave profile 


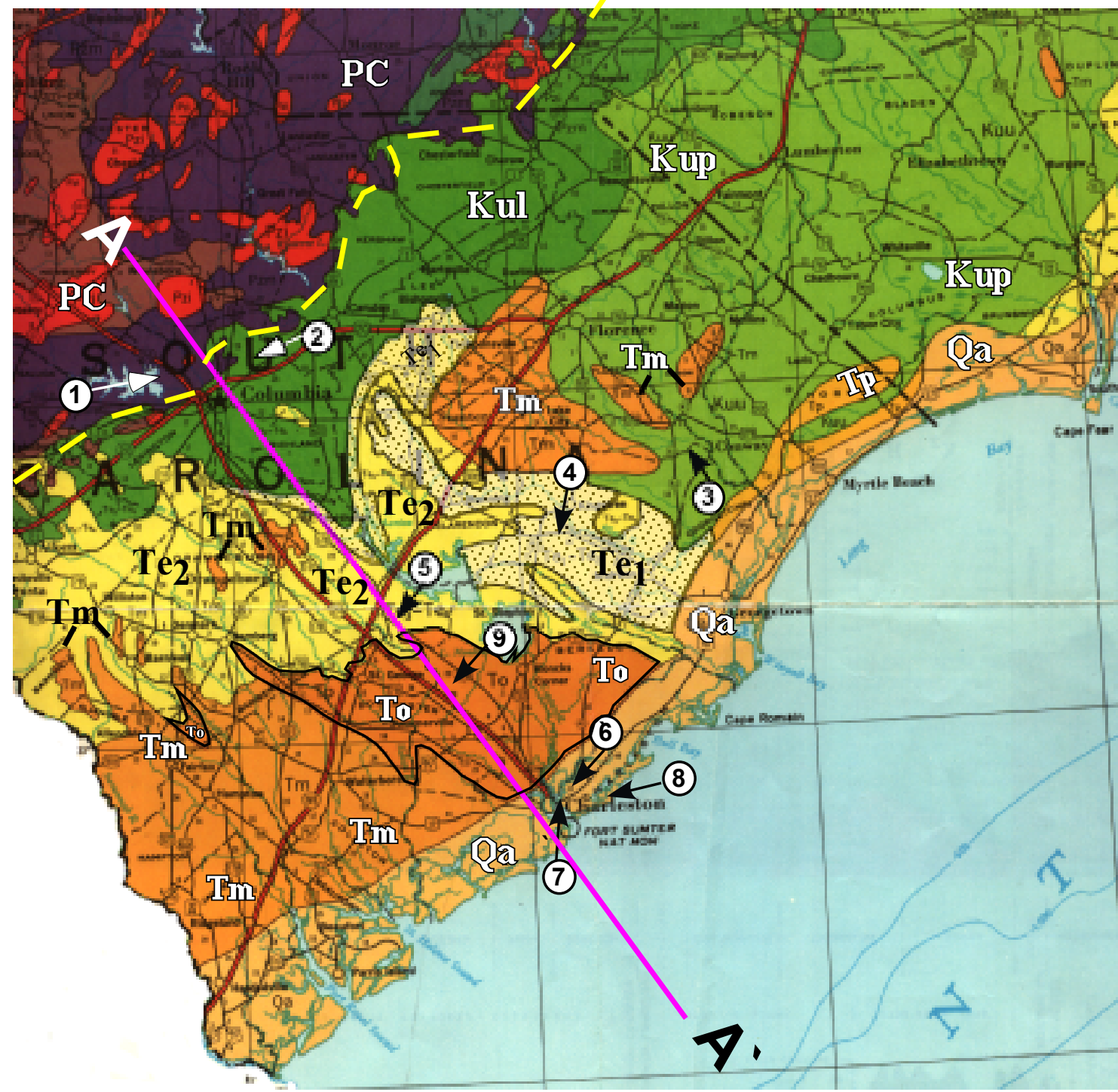

Generalized Geologic Units

\begin{tabular}{|c|c|}
\hline Qa & Surface soils and fill, Pleistocene and Holocene of alluvial and marine origin \\
\hline Tp & Pliocene sandy shell marl \\
\hline Tm & Miocene sandy phosphatic marl, shaley (Hawthorn Group) \\
\hline To & Oligocene massive phosphatic marl (Cooper Group-Ashley Fm.) \\
\hline $\mathrm{Te}_{2}$ & $\begin{array}{l}\text { Eocene upper units- calcilutite and limestones (Cooper Gp - Parkers Ferry Fm. ) } \\
\text { Santee Ls. }\end{array}$ \\
\hline Tes: & $\begin{array}{l}\text { Eocene lower units-clayey to sandy siltstone and limestone (Wilcox Group, Black } \\
\text { Mingo Fm.) }\end{array}$ \\
\hline Kup & Cretaceous- calcareous clayey sands and limestone (Peedee Fm.) \\
\hline Kt & Cretaceous- predominantly clean to silty sands and pure clay (Tuscaloosa Fm.) \\
\hline$P c$ & $\begin{array}{l}\text { Precambrian- metamorphosed early Paleozoic and older sedimentary and } \\
\text { volcanic rocks and granitic intrusions (Carolina Slate Group) }\end{array}$ \\
\hline
\end{tabular}

Figure $1 A$. 

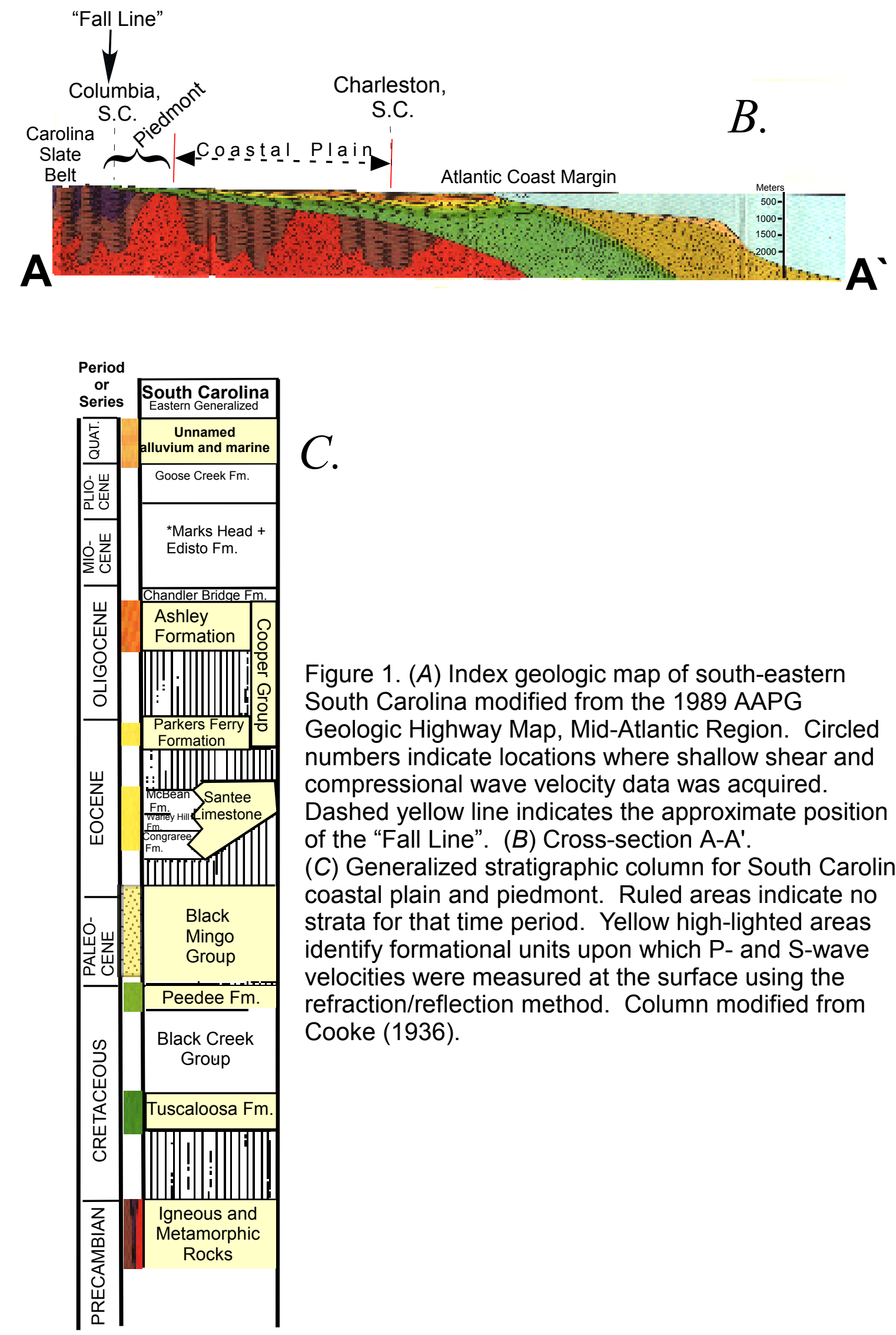

Figure 1. $(A)$ Index geologic map of south-eastern South Carolina modified from the 1989 AAPG Geologic Highway Map, Mid-Atlantic Region. Circled numbers indicate locations where shallow shear and compressional wave velocity data was acquired. Dashed yellow line indicates the approximate position of the "Fall Line". (B) Cross-section A-A'.

(C) Generalized stratigraphic column for South Carolina coastal plain and piedmont. Ruled areas indicate no strata for that time period. Yellow high-lighted areas identify formational units upon which P- and S-wave velocities were measured at the surface using the refraction/reflection method. Column modified from Cooke (1936). 
lengths resulted in a maximum survey depth range of about 30 to $80 \mathrm{~m}$. Similar studies to characterize near-surface materials using surface seismic methods have been conducted by Campbell and Duke (1976), Harris et al. (1994) and Williams et al. (1994, 1998, 1999).

Compressional P-wave velocity data were recorded using an in-line spread of $608 \mathrm{-Hz}$, vertical-component geophones. Geophone spacing for sites 6, 7 and 9 (Citadel, U.S. Highway. 17 and USNSN) was $3 \mathrm{~m}$ with geophone spacing for all other sites being $5 \mathrm{~m}$. P-wave energy was generated by vertically striking a steel plate with a 4-kg sledgehammer. Recording parameters for both S-wave and P-wave surveys are listed in Table 1.

Table 1. - Seismic-Refraction/Reflection Data Recording Parameters

\begin{tabular}{|ll|}
\hline Recording system & Geometrics Strata View 24-bit seismograph (30 to 60 channels) \\
\hline Sampling interval & 0.001 seconds \\
\hline Record length & 1 second \\
\hline Recording format & SEG-2 \\
\hline Geophones & 30 to 60 4.5-Hz horizontal or 8-Hz vertical \\
\hline Geophone array & Linear with single phones at 1.5- to 5-m intervals \\
\hline Source & $\begin{array}{l}\text { 4.0-kg sledgehammer on wood timber (S-wave) or steel plate (P- } \\
\text { wave) }\end{array}$ \\
\hline $\begin{array}{l}\text { Source array } \\
\text { geometry }\end{array}$ & Linear, 87 to 177-m array lengths \\
\hline
\end{tabular}

\section{Seismic Data Processing and Interpretation}

Representative S-wave seismic refraction/reflection profiles for nine sites in South Carolina are shown in Figure 2. We interpreted refraction data from both the S-wave and P-wave surveys using the slope-intercept method described by Mooney (1984). Data interpretation generally produced profile columns consisting of 2 or 3 distinct velocity layers for each site. In cases where no additional $S$-wave layers were detected below about $20 \mathrm{~m}$ by refraction methods, the maximum imaging depth was approximated by assuming that a higher velocity layer would have been detected on the next geophone beyond the end of the profile (Mooney, 1984). S-wave and P-wave velocity-versus-depth profiles for data collected at all sites are presented in Figure 3 and Figure 4 respectively.

Typically, and to be expected, the seismic data suggest that at locations tested, none of the mapped geologic formations were present at the surface in a pristine, unweathered state. Always present at the surface is a low-velocity layer that consists of at least a few meters of unconsolidated to partially weathered material that overlie a higher velocity layer. This is seen in the seismic data as low-velocity direct arrivals and refracted phases that are the first arrivals near the seismic source input position (Figure 2).

Using results from Figure 3 we calculated the average $V_{S}$ to $30-m$ depth $\left(V_{S 30}\right)$ at each site. According to NEHRP guidelines, $\mathrm{V}_{\mathrm{s} 30}$, is determined by:

$$
\mathrm{Vs}_{30}=\frac{\sum_{i=1}^{n} d_{i}}{\sum_{i=1}^{n} \frac{d_{i}}{V_{s i}}}
$$



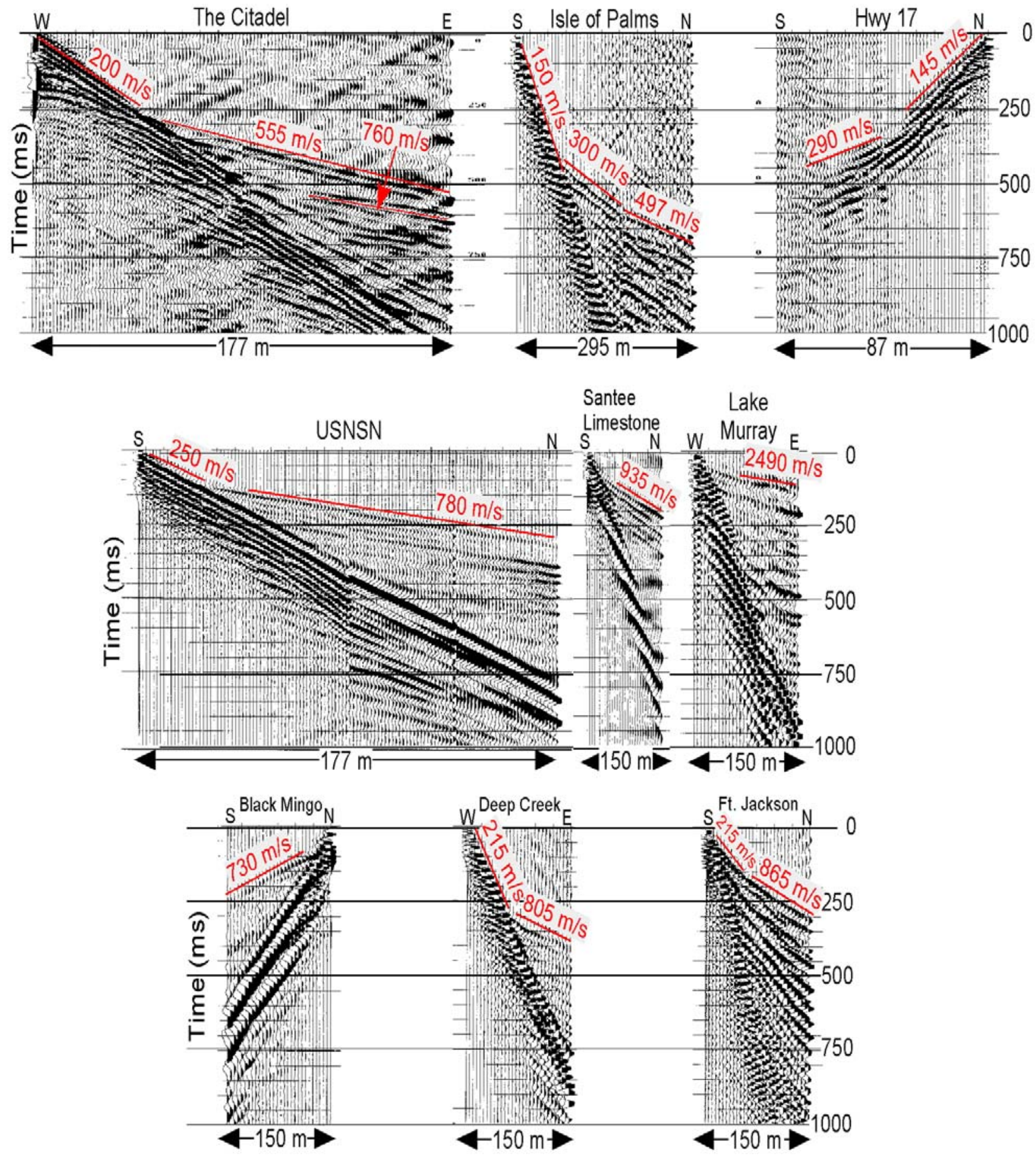

Figure 2. Representative shear (S)-wave seismic refraction/reflection profiles from each of the 9 sites in South Carolina. Red lines on seismic data highlight refractions phases with the seismic velocity for that phase annotated above the red line. 


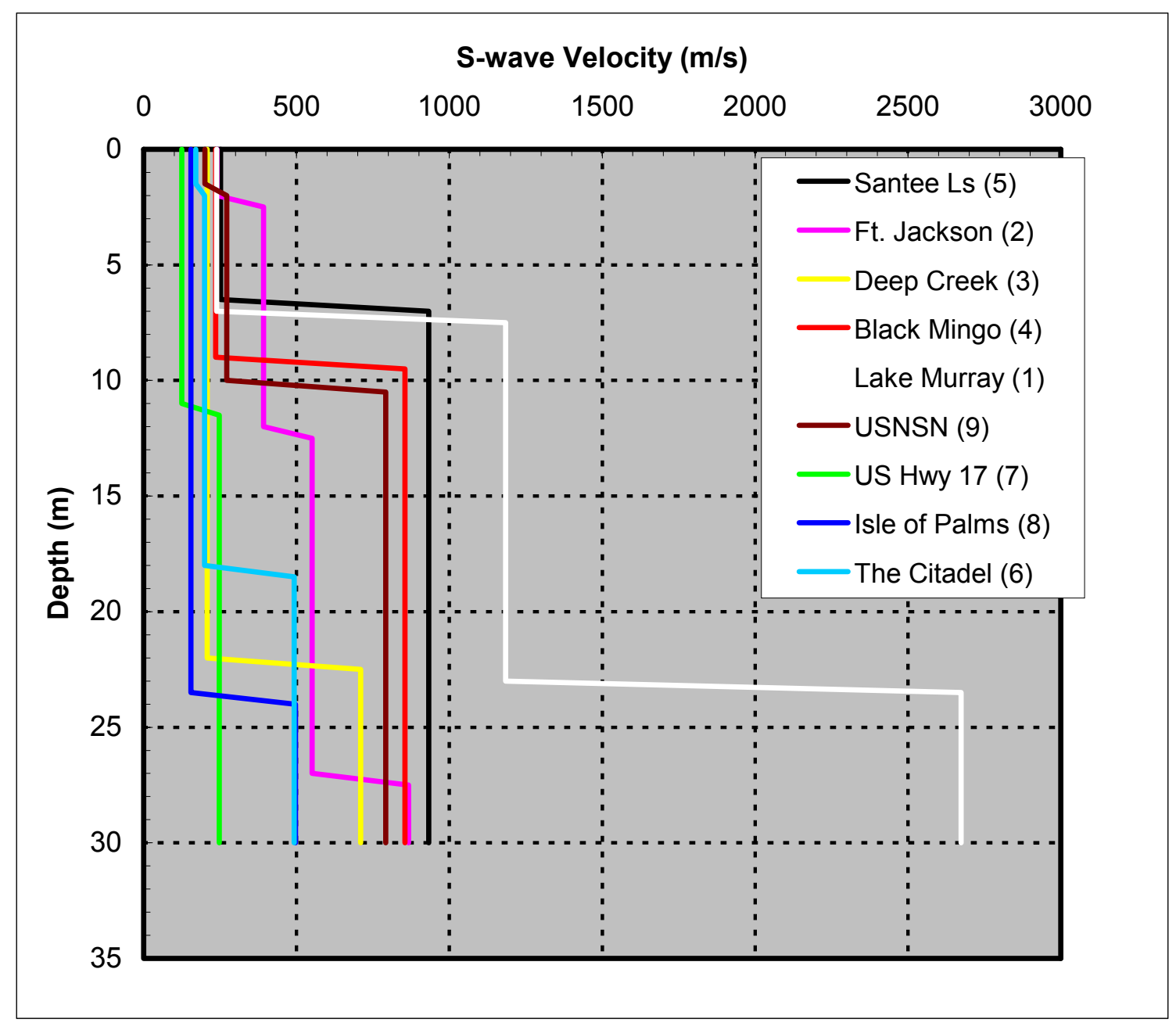

Figure 3. S-wave velocity versus depth profiles for each of the nine sites studied in South Carolina. Numbers in legend are referenced to site locations on Figure $1 \mathrm{~A}$.

Table 3. South Carolina site locations, surficial geology, and S-wave velocity measurements.

\begin{tabular}{|c|c|c|c|c|c|c|c|}
\hline Site Name & $\begin{array}{l}\text { Latitude } \\
{ }^{0} \text { North }\end{array}$ & $\begin{array}{c}\text { Longitude } \\
{ }^{\circ} \text { West }\end{array}$ & $\begin{array}{l}\text { Surficial } \\
\text { Geology }\end{array}$ & $\begin{array}{l}V_{\mathrm{s30}} \\
(\mathrm{m} / \mathrm{s})\end{array}$ & $\begin{array}{c}\text { NEHRP } \\
\text { Soil } \\
\text { Profile } \\
\text { Type } \\
\end{array}$ & $\begin{array}{c}\text { Highest Vs } \\
\text { in the upper } \\
50 \mathrm{~m}(\mathrm{~m} / \mathrm{s})\end{array}$ & Description \\
\hline Lake Murray Spillway & 35.052 & 81.210 & fill, $\mathrm{Pz}$ & 661 & $\mathrm{C}^{*} / \mathrm{A}$ & 2674; @23 m & Carolina Slate Group $(\mathrm{Pz})$ \\
\hline Fort Jackson & 34.028 & 90.912 & $\mathrm{~K}_{\mathrm{u}}$ & 465 & $\mathrm{C}$ & 866;@27 m & Tuscaloosa Fm \\
\hline Deep Creek School. & 33.699 & 79.351 & $\mathrm{Q} ?, \mathrm{~K}_{\mathrm{u}}$ & 246 & $\mathrm{D}$ & 710;@22 m & Q over Peedee Fm \\
\hline Black Mingo & 33.551 & 79.933 & $\mathrm{Q}, \mathrm{T}_{1}$ & 477 & $\mathrm{C}$ & 855;@9m & Q over Eocene Wilcox Grp \\
\hline Santee Ls. & 33.235 & 80.433 & $\mathrm{~T}_{1}$ & 583 & $\mathrm{C}$ & 932;@7 m & Santee Limestone \\
\hline The Citadel, Charles. & 32.798 & 79.958 & $\mathrm{Q}, \mathrm{T}_{\mathrm{u}}$ & 248 & $\mathrm{D}$ & 795;@78m & Q over $T_{u}$ (Cooper Group) \\
\hline US Hwy. 17, Charles. & 32.785 & 79.955 & fill, Q & 182 & $\mathrm{D}$ & 247;@11m & Q over $T_{u}$ (Cooper Group) \\
\hline Isle of Palms & 32.795 & 79.775 & $\mathrm{Q}_{\mathrm{h}}, \mathrm{T}_{\mathrm{u}}$ & 179 & $\mathrm{E}$ & 497;@23 m & Q over $\mathrm{T}_{\mathrm{u}}$ (Cooper Group) \\
\hline USNSN & 33.106 & 80.178 & $\mathrm{Q}, \mathrm{T}_{\mathrm{u}}$ & 464 & $\mathrm{C}$ & 792;@10m & Q over $\mathrm{T}_{\mathrm{u}}$ (Cooper Group) \\
\hline
\end{tabular}

$\mathrm{Q}$ - Quaternary; $\mathrm{T}_{\mathrm{u}}$ - upper Tertiary; $\mathrm{T}_{1}$ - lower Tertiary; $\mathrm{K}_{\mathrm{u}}$ - upper; Cretaceous; $\mathrm{Pz}-$ Paleozoic;; [C*/A] is text for explanation of dual classification. 
Table 4. South Carolina site locations, surficial geology, and P-wave velocity measurements.

\begin{tabular}{|c|c|c|c|c|c|}
\hline Site Name & $\begin{array}{l}\text { Latitude } \\
{ }^{0} \text { North }\end{array}$ & $\begin{array}{c}\text { Longitude } \\
{ }^{0} \text { West }\end{array}$ & $\begin{array}{l}\text { Surficial } \\
\text { Geology }\end{array}$ & $\begin{array}{l}\text { Highest } \mathrm{Vp} \text { in the } \\
\text { upper } 50 \mathrm{~m}(\mathrm{~m} / \mathrm{s})\end{array}$ & Description \\
\hline Lake Murray Spillway & 35.0525 & 81.210 & fill, $\mathrm{Pz}$ & $4262 ; @ 5.5 \mathrm{~m}$ & Carolina Slate Group $(\mathrm{Pz})$ \\
\hline Fort Jackson & 34.0289 & 90.912 & $\mathrm{~K}_{\mathrm{u}}$ & 1996;@10m & Tuscaloosa Fm \\
\hline Deep Creek School & 33.699 & 79.351 & $\mathrm{Q} ?, \mathrm{~K}_{\mathrm{u}}$ & 1879;@14 m & Q over Peedee Fm \\
\hline Black Mingo & 33.551 & 79.933 & $\mathrm{Q}, \mathrm{T}_{1}$ & 2248;@4 m & Q over Eocene Wilcox Grp \\
\hline Santee Ls. & 33.235 & 80.433 & $\mathrm{~T}_{1}$ & 2182;@14m & Santee Limestone \\
\hline The Citadel, Charleston & 32.798 & 79.958 & $\mathrm{Q}, \mathrm{T}_{\mathrm{u}}$ & 1737;@4m & Q over $T_{u}$ (Cooper Group) \\
\hline US Hwy. 17, Charleston & 32.785 & 79.955 & fill, Q, & 2894;@17 m* & Q over $T_{u}$ (Cooper Group) \\
\hline Isle of Palms & 32.795 & 79.775 & $\mathrm{Q}_{\mathrm{h}}, \mathrm{T}_{\mathrm{u}}$ & 1573;@7.5 m & Q over $T_{u}$ (Cooper Group) \\
\hline USNSN & 33.106 & 80.178 & $\mathrm{Q}, \mathrm{T}_{\mathrm{u}}$ & 1893;@4m & Q over $\mathrm{T}_{\mathrm{u}}($ Cooper Group $)$ \\
\hline
\end{tabular}

$\mathrm{Q}$ - Quaternary; $\mathrm{T}_{\mathrm{u}}$ - upper Tertiary; $\mathrm{T}_{1}$ - lower Tertiary; $\mathrm{K}_{\mathrm{u}}$ - upper Cretaceous; Pz - Paleozoic;;

\section{P-wave Velocity $(\mathrm{m} / \mathrm{s})$}

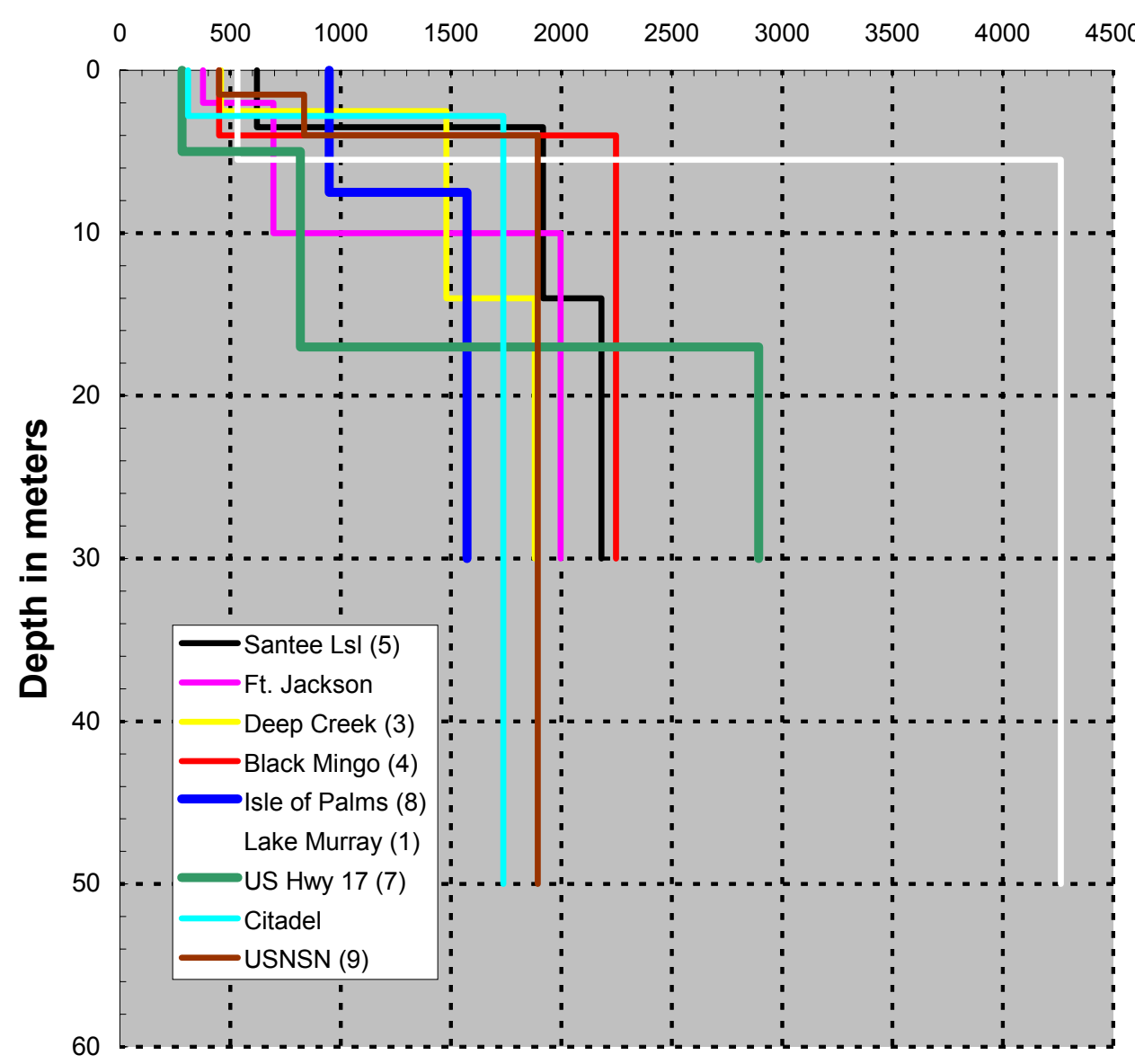

Figure 4. P-wave velocity-versus-depth profiles for each of the nine sites studied in South Carolina. Numbers in legend are referenced to site locations in Figure $1 \mathrm{~A}$. 
where $d_{i}$ is the thickness of the $i$ th layer between 0 and $30 \mathrm{~m}$ and $V_{s i}$ is the velocity of the $i$ th layer (Building Seismic Safety Council, 1997). Table 2 shows the NEHRP classification code as it is defined in terms of $V_{S}$.

Table 2. - Site Categories in New Building Codes (NEHRP 1994; UBC 1997)

\begin{tabular}{c|c|c}
\hline $\begin{array}{c}\text { Soil Profile } \\
\text { Type }\end{array}$ & Rock/Soil Description & $\begin{array}{c}\text { Average S-wave Velocity (m/s) } \\
\text { top 30 m }\end{array}$ \\
\hline A & Hard rock & $>1500$ \\
B & Rock & $760-1500$ \\
C & Very dense soil/soft rock & $360-760$ \\
D & Stiff soil & $180-360$ \\
E & Soft soil & $<180$ \\
F & Special soils requiring & \\
& site-specific evaluation & \\
\hline
\end{tabular}

Tables 3 and 4 present interpreted S- and P-wave results and provide information on site location coordinates, geologic map unit symbols and descriptions (see Figures $1 A$ and $C$ ) and both the average and range of interpreted velocity values. Table 3 also contains calculated $\mathrm{V}_{\mathrm{S} 30}$ and NEHRP soil profile type classification codes (see Table 2 for explanation). In some cases, values listed in the "Highest Vs in the upper $50 \mathrm{~m}$ " column on Table 3 and Figures 2 and 3 differ from velocities shown on the Figure 2 refraction/reflection profiles. This happens because the data in Table 3 are calculated averages derived from both the Figure 2 profiles and from the reverse profiles obtained at each site (not shown).

\section{DISCUSSION OF SITE VELOCITIES}

The histogram chart (Figure 5) illustrates the $\mathrm{V}_{\mathrm{S}}$ range for each successively higher velocity layer identified by site. For three sites (The Citadel, USNSN and Ft. Jackson), a very thin surface layer, generally less than $2 \mathrm{~m}$ thick, was identified. If this layer was incorporated into the next higher velocity layer, the overall thickness of the $\mathrm{V}_{1}$ layer at all nine sites surveyed would range from $6.5 \mathrm{~m}$ to $22 \mathrm{~m}$. All interpreted velocity layer values (including layers less than $2 \mathrm{~m}$ thick) are shown in Figure 5. When viewing Figure 5, it should be noted that the age of surface mapped (and underlying) geologic units increases from left to right.

All velocity layer interpretations are based on reversed profiles, except for the U.S. Highway 17 site (Figure $1 A \# 7$ ) where space limitations prevented the acquisition of a far offset reverse profile on the south end of the array. These individual layer results, including the very thin surface unit discussed above, are graphed as side-by-side P- and S-wave velocity columns in Figures 6 and 7. In general, unit thickness and degree of velocity contrast between layers is clearly evident in Figures 3, 4, 6 and 7.

Typical of data collected from these types of stratigraphic formations, the thicknesses of the $\mathrm{P}$ - and S-wave velocity layers differ. This difference is in part a result of the influence that the water table and vadose zone have on the propagation of P-wave energy. Shear-wave energy propagation for the most part is unaffected by the water table and we can, therefore, assume for discussion that the various near-surface (upper $50 \mathrm{~m}$ ) velocity layers represent changes in 


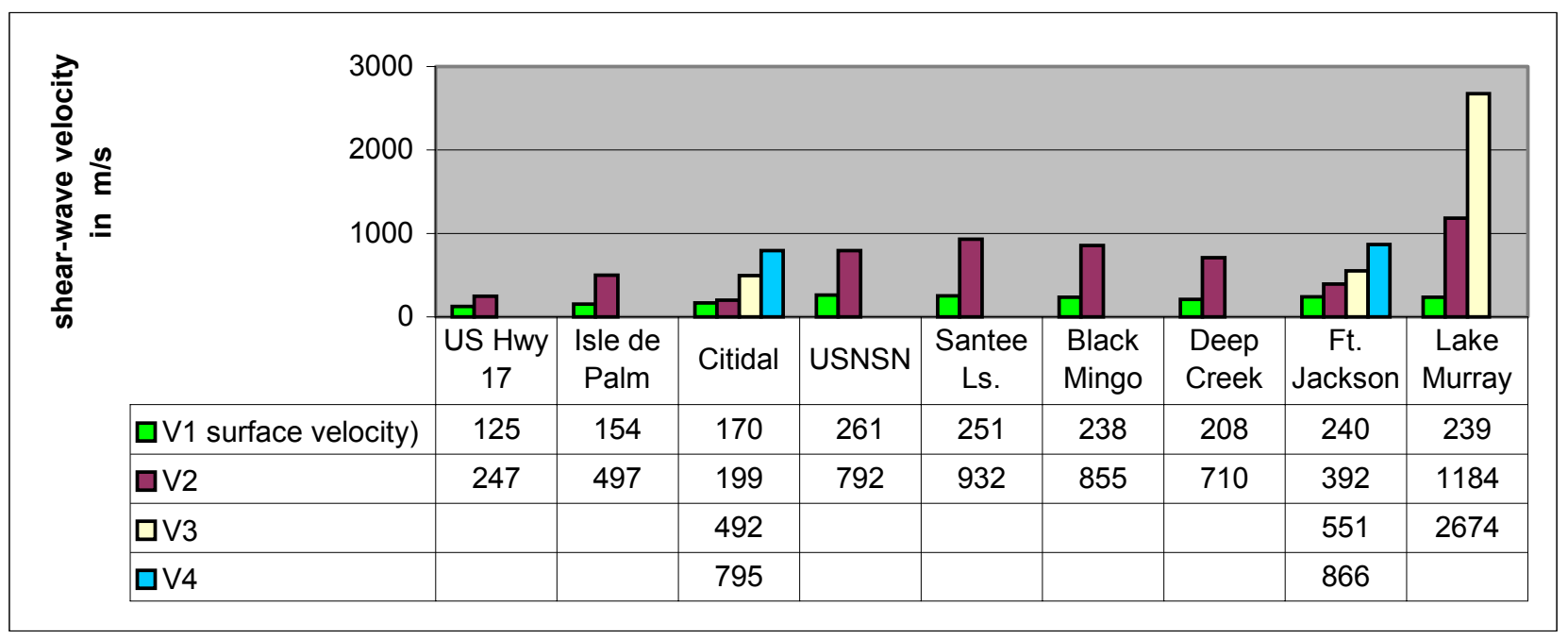

Figure 5. Histogram displaying the relationship of the surficial $\left(\mathrm{V}_{1}\right)$ layer (regardless of thickness) to the underlying higher velocity layers for each site. In general, the geologic age of the bedrock units sampled at each site increases from left to right. 
lithology and/or physical properties. Because $\mathrm{V}_{\mathrm{S}}$ layer contrasts are of primary importance to the engineering community and in seismological modeling of site response, the following discussion will focus on the S-wave information with comments on $\mathrm{P}$-wave data inserted where appropriate.

Although multiple velocity layers were determined at all sites, the sites themselves fall into two groups. The first group consists of sites where only a single geologically mapped formation was sampled (Lake Murray (1), Ft. Jackson (2), Deep Creek (3), Black Mingo (4) and Santee Ls. (5)). Velocity columns for this group are presented in Figure 6. On the P and S-wave velocity columns for this group, the velocity layers $\left(\mathrm{V}_{1}, \mathrm{~V}_{2}\right.$ and $\left.\mathrm{V}_{3}\right)$ are indicated by yellow, blue and light brown respectively.

The second group consists of sites where multiple geologic formations of various ages (Holocene and older) were sampled and are located in and around the Charleston, S.C. region. Velocity column data for these sites (Citadel (6), U.S. Hwy. 17 (7), Isle de Palm (8) and USNSN (9)) is presented in Figure 7. Based on existing geologic maps, cross sections and personal communication (Weems, 2002), we have tentatively correlated some of the S-wave velocity layers in this group with specific geologic formations.

\section{Single Geologic Unit Sites (see Figure 6)}

\section{Lake Murray, site 1}

We interpret three distinct S-wave velocity layers at this site. The $\mathrm{V}_{1}$ layer $(0-7 \mathrm{~m})$ velocity is interpreted to be surface soil and loose debris partially accumulated during the construction of the Lake Murray dam spillway. The intermediate velocity layer (7-23 $\mathrm{m})$ is interpreted to correlate with weathered and fractured Carolina Slate Group bedrock. We interpret the higher velocity layer $(23-50 \mathrm{~m})$ to represent a transition to more competent bedrock. The $\mathrm{V}_{\mathrm{S} 30}$ NEHRP soil profile type classification determined for this site is " $\mathrm{C}$ " (see Tables 2 and 3). This $\mathrm{V}_{\mathrm{S} 30}$ value strongly reflects the influence of the thick $\mathrm{V}_{1}$ and $\mathrm{V}_{2}$ layers that predominantly consist of soil, rock rubble and transitionally weathered bedrock. If the $7 \mathrm{~m}$ thick $\mathrm{V}_{1}$ layer (interpreted to be soil and loose debris) were discarded and the $\mathrm{V}_{\mathrm{S} 30}$ NEHRP soil profile type classification was calculated using the $V_{2}$ and $V_{3}$ layer velocities, a classification type "A" (hard rock) would be determined.

Bonini and Woollard (1960) determined a P-wave velocity range of 4,700 to $5,500 \mathrm{~m} / \mathrm{s}$ for Carolina Slate Group rocks (predominantly composed of metamorphic gneiss, schist and volcanic rock) exposed along the "Fall Line" near our site. They also stated that often three distinct velocity layers were observed, which they interpreted to represent a weathered zone (approximately 0-9 $\mathrm{m}$ thick with an average velocity of $1,190 \mathrm{~m} / \mathrm{s}$ ) underlain by a transitional zone (approximately $22 \mathrm{~m}$ thick with an average velocity of 2,970 m/s) over fresh bedrock. From our data (\#1, Figure $1 A$ ), we interpret a 5 -m-thick $\mathrm{V}_{1}$ layer with a velocity of $532 \mathrm{~m} / \mathrm{s}$ and a $\mathrm{V}_{2}$ layer from $5-50 \mathrm{~m}$ with a velocity of $4,262 \mathrm{~m} / \mathrm{s}$. Our calculated $\mathrm{V}_{1}$ layer value reflects the presence of soil and fractured debris in the near surface. The $\mathrm{V}_{2}$ velocity layer has a value that falls midway between the transitional and fresh bedrock values cited by Bonini and Woollard (1960). 


\section{Velocity Columns for Single Formation Sites}

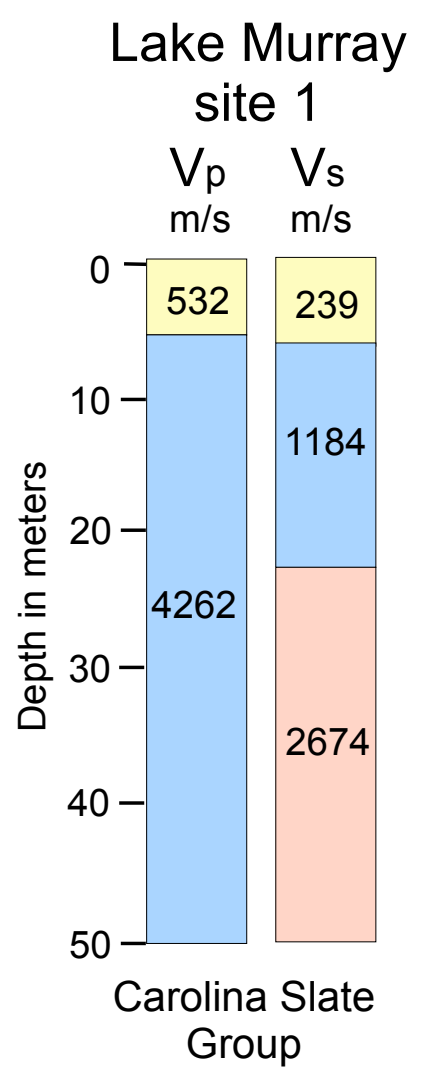

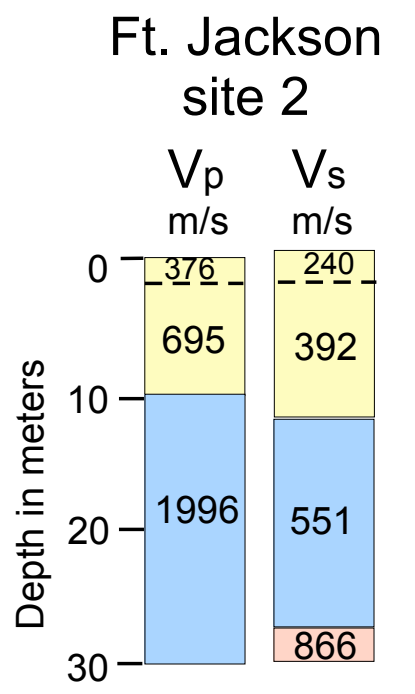

Tuscaloosa Fm. Upper Cretaceous
Deep Ck. site 3

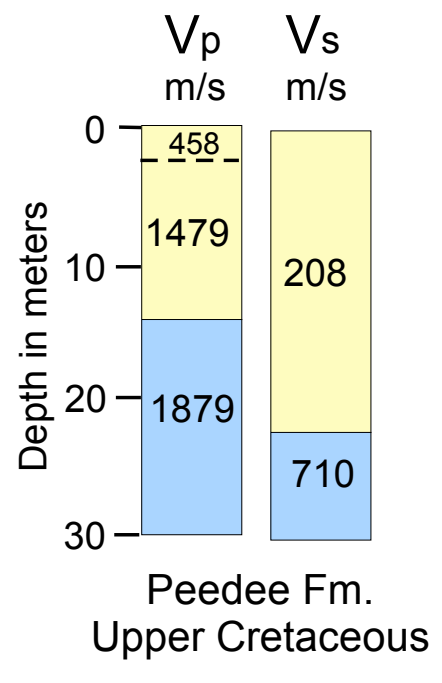

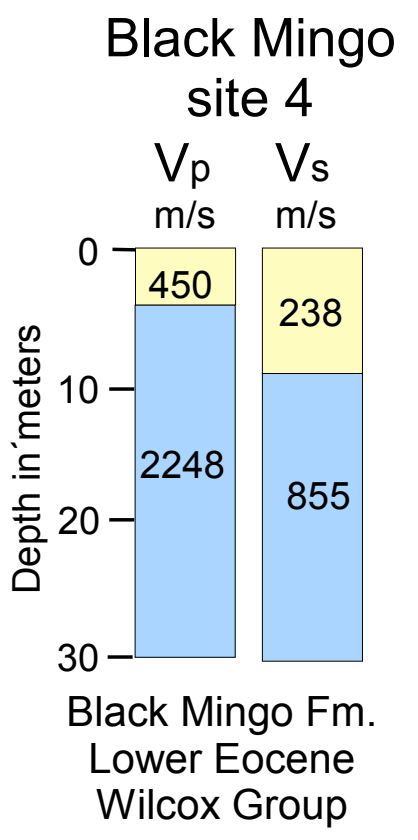

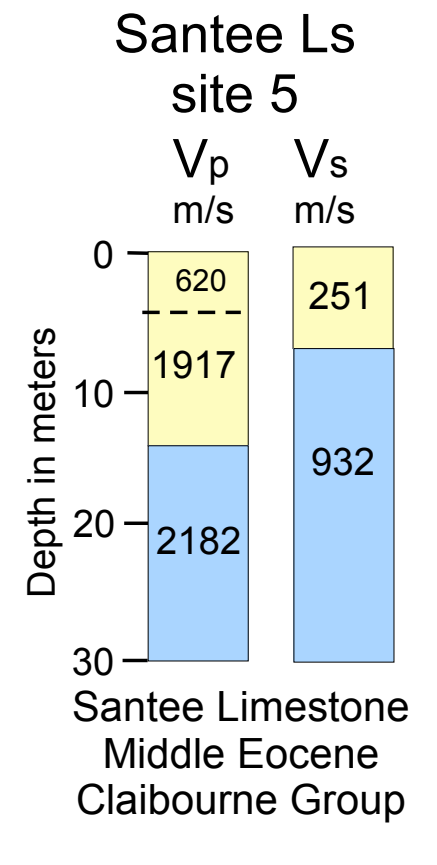

Figure 6. Velocity profiles constructed from data gathered at sites where geologic mapping (Cooke, 1936) indicated a single formational unit could be sampled. On both $P$ - and $S$-wave velocity columns, successively higher velocity layers $\left(V_{1}, V_{2}\right.$ and $\left.V_{3}\right)$, indicated by yellow, blue and light brown respectively, are described in the text. Layer velocity values are based on a calculated average obtained from reversed data profiles. 


\section{Velocity Columns for Multiple Formation Sites}

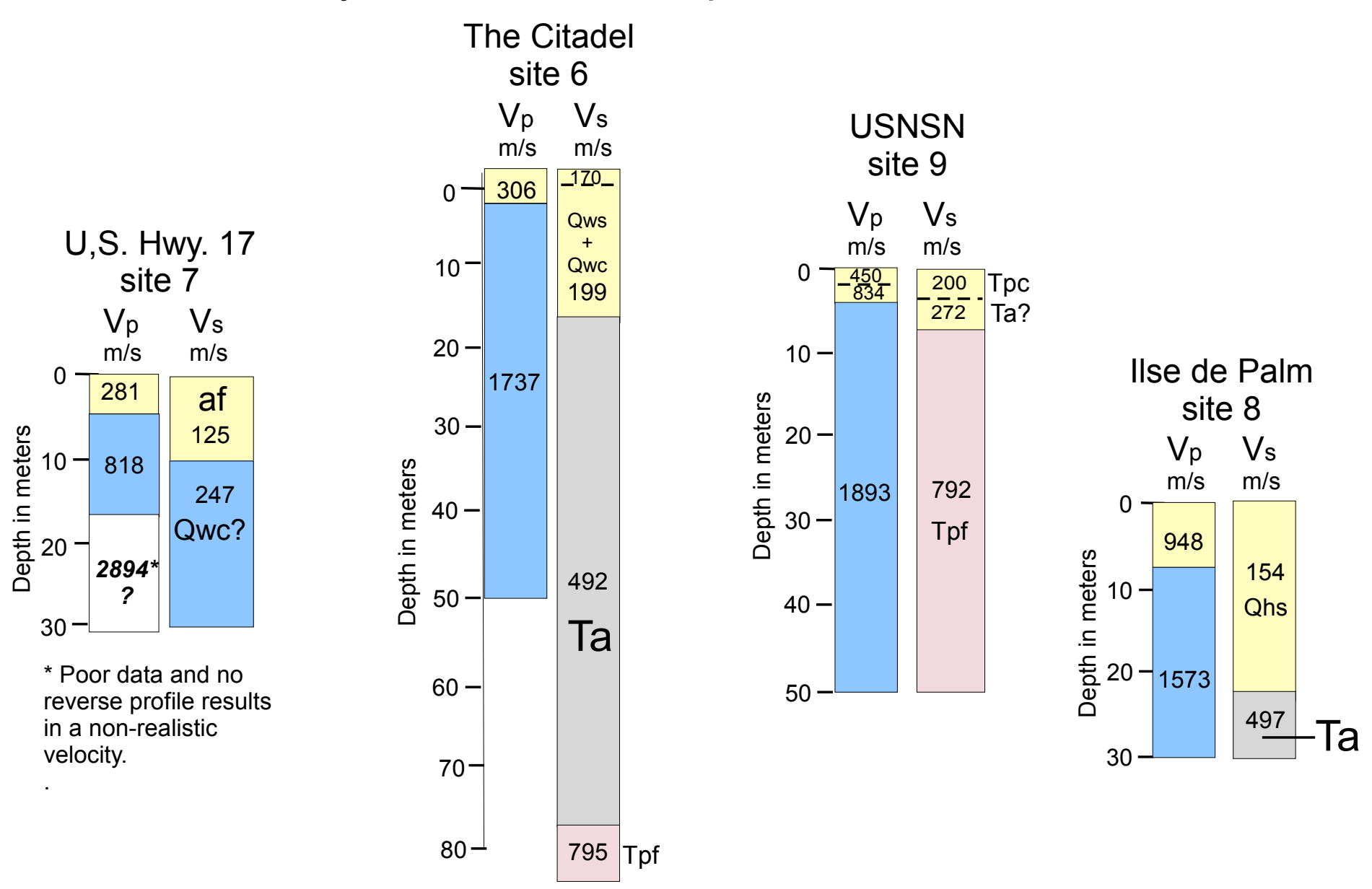

Figure 7. Velocity profiles constructed from data gathered at sites where geologic mapping (Cooke, 1936; Weems and Lemon, 1984, 1987 and 1993) indicate that multiple formational unit would be sampled. On the P-wave velocity column, successively higher velocity layers $\left(\mathrm{V}_{1}\right.$ and $\left.\mathrm{V}_{2}\right)$ are indicated by yellow and blue. Where possible, $\mathrm{S}$-wave velocity values have been correlated with mapped geologic units (see text for discussion). Layer velocity values are based on a calculated average obtained from reversed data profiles. The high P-wave value indicated by an * on the U.S. Hwy. 17 profiles is believed to be the result of an up-dip profile that can not be substantiated since a reverse profile at this site was unattainable. 


\section{Ft. Jackson, site 2}

This site, located southeast of the "Fall Line" (\#2 on Figure 1A), sampled the upper Cretaceous Tuscaloosa Formation, which lies unconformably upon the Carolina Slate Group and is the oldest outcropping sedimentary unit in the Coastal Plain province of South Carolina. This formation was deposited under non-marine fluvial conditions and is described by Cooke (1936) as containing a variety of interbedded lithologies.

Both the P- and S-wave data show a low-velocity layer in the upper $2 \mathrm{~m}$ of the site. The near-surface material at this site consists of unconsolidated very fine to medium, loose, permeable sand, locally derived from the Tuscaloosa Formation (Paradesse et al, 1953). The two-meter-thick low-velocity (P-wave $=376 \mathrm{~m} / \mathrm{s}$ and $\mathrm{S}$-wave $=240 \mathrm{~m} / \mathrm{s}$ ) layer is interpreted to correlate with this mantle of colluvial and eolian material (see Figure 6). The next interpreted velocity boundary occurs at a depth of $10 \mathrm{~m}$ for P-wave and $12 \mathrm{~m}$ for $\mathrm{S}$-wave. This $\mathrm{V}_{2}$ layer probably represents a weathered transitional zone. The $\mathrm{V}_{4} \mathrm{~S}$-wave velocity layer identified at a depth of $27 \mathrm{~m}$ may represent a change in formation and/or a facies change (i.e. channel fill, dense clay unit). The $\mathrm{V}_{\mathrm{S} 30}$ NEHRP soil profile type classification for this site is " $\mathrm{C}$ ".

\section{Deep Creek, site 3}

The youngest of the upper Cretaceous units, the Peedee Formation, was deposited in an open marine environment and consists of interbedded clayey sand, impure limestone and massive dark clays (Cooke, 1936). Both S- and P-wave velocity data (Figures 3 and 4) show two distinct layers. Figure 4 (P-wave data) shows a relatively thin surficial layer. The S-wave column shows a thick $(22 \mathrm{~m}) \mathrm{V}_{1}$ layer with a relatively low velocity $(208 \mathrm{~m} / \mathrm{s})$ in comparison to the previously discussed upper Cretaceous site. Possible explanations for the relatively slow velocity of this thick layer are deep weathering and/or strata with physical properties that produce a slower than anticipated velocity. The higher-velocity layer is inferred to represent fresh, (or at least relatively less weathered) competent bedrock. Although this site has a $\mathrm{V}_{2}$ layer velocity that correlates with a very dense soil/soft rock classification, the very thick $(22 \mathrm{~m}) \mathrm{V}_{1}$ layer with a relatively low velocity $(208 \mathrm{~m} / \mathrm{s})$ results in a $\mathrm{V}_{\mathrm{S} 30}$ NEHRP soil profile type classification of "D", indicating that this site has the properties of a stiff soil.

\section{Black Mingo, site 4}

The Paleocene to lower Eocene Black Mingo Formation is part of the regionally widespread Wilcox Group, which is found throughout the Atlantic Coast, Gulf Coast and Mississippi Embayment states. Although the Black Mingo Formation and the previously discussed Peedee Formation were deposited under similar environmental conditions, this unit is described by Cooke (1936) as predominantly consisting of partly lithified to weakly consolidated pebbly sandstone interbedded with laminated to hard fossiliferous shale. Even though the site surface conditions were that of an unconsolidated pebbly sand the calculated S-wave lowvelocity $\mathrm{V}_{1}$ layer thickness was considerably thinner in comparison to what was determined for the Peedee Formation site (\#3). Additionally, when compared to the older Peedee Formation, both $\mathrm{P}$ - and $\mathrm{S}$-wave $\mathrm{V}_{2}$ velocities are higher, reflecting the more lithified nature of this unit. The $\mathrm{S}$-wave $\mathrm{V}_{2}$ layer velocity $(855 \mathrm{~m} / \mathrm{s})$ is the second highest recorded for sedimentary units and is less than $10 \%$ slower than the $\mathrm{V}_{2}$ velocity recorded for the Santee Limestone. The $\mathrm{V}_{\mathrm{S} 30} \mathrm{NEHRP}$ soil profile type classification for this site is "C", a very dense soil/soft rock. 


\section{Santee Limestone, site 5}

The Middle Eocene Santee Limestone was sampled at this site. This unit is composed of nearly pure white to yellowish limestone. The unit was variably weathered at the surface, with some zones of hard rock making emplacement of spiked geophones difficult. The S-wave $\mathrm{V}_{1}$ velocity was similar in value to what was determined at the other sites. The $\mathrm{S}$-wave $\mathrm{V}_{2}$ velocity was the highest $(932 \mathrm{~m} / \mathrm{s})$ encountered for sedimentary formations sampled in this survey. The $\mathrm{V}_{\mathrm{S} 30}$ NEHRP soil profile type classification for this site is " $\mathrm{C}$ ".

\section{Multiple Geologic Unit Sites, Figure 7}

At these sites (\#'s 6, 7, 8, 9 on figure $1 A$ ), the seismic refraction/reflection data produced velocity profiles that ranged in depth from 30 to $80 \mathrm{~m}$. Geologic mapping (Cooke, 1936; Weems and Lemon, 1984, 1987 and 1993;Weems et al., 1997; Weems and Lewis, 2002) indicate that multiple formational units would be sampled within these depth ranges. Formations of the Cooper Group unconformably overlie the middle Eocene Santee Limestone and, in turn, are overlain by successively younger strata in a down-dip southeasterly direction. However, Weems and Lewis (2002), using detailed geologic mapping and over 1000 auger holes, showed that extensive erosion and deposition has resulted in a complex stratigraphic architecture. With respect to the Cooper Group formations (predominantly the older Parkers Ferry and the younger Ashley) contouring and cross-sections indicate a spatially large variation in thickness for both units with the result being that over a relatively short distance, stratigraphic units are found in both a traditional "layer cake" stack as well as a "side- by-side" stratigraphic arrangement.

We were able to use recently published geologic map cross-sections and personal communications to tentatively correlate $S$-wave $V_{1}$ layer (yellow), $V_{2}$, and $V_{3}$ (shown in pink or gray and identified with formational nomenclature symbols on Figure 7) with known geologic units in the Charleston, S.C. region. Nomenclature symbols used are: (af) modern artificial fill, (Qhs) Holocene beach and barrier island, (Qws/Qwc) Waldo Formation [Pleistocene, about 70$120 \mathrm{ka}$ ], (Ta) Ashley Formation of the Cooper Group [Oligocene, about $30 \mathrm{Ma}$ and (Tpf) Parkers Ferry Formation of the Cooper Group [late Eocene, about 38 Ma], (Weems et al, 1997; Weems and Lewis, 2002).

\section{USNSN, site 9}

This site is geographically located in an area where Pleistocene and Cooper Group formations unconformably overlie Santee Limestone (geologic symbol "To" on Figure. 1A). Both P- and S-wave velocity profiles show two distinct layers (Figure 7). The S-wave profile shows an interpreted $V_{1}$ layer that is composed of a 2-3 m thick surficial unit $(200 \mathrm{~m} / \mathrm{s})$ over a 3 $4 \mathrm{~m}$ thick $(272 \mathrm{~m} / \mathrm{s})$ sub-unit. This low velocity layer in turn overlies a $\mathrm{V}_{2}$ layer that extends to an interpreted depth of approximately $50 \mathrm{~m}$. The P-wave profile shows a similar thickness sequence.

Detailed mapping, nearby auger hole data and personal communication (Weems, 2002) provide enough information to tentatively correlate the velocity layers at this site with known geologic units. Force (1978) estimated an overburden thickness of approximately $8 \mathrm{~m}$ in this area, which correlates well with our interpreted $V_{1}$ layer thickness of 7-8 m. We interpret the upper $\mathrm{V}_{1}$ unit to correlate with the mapped Penholoway Formation ((Qpc) lower Pleistocene, 730 to $970 \mathrm{ka}$ ) which is inferred to be 3 to $5 \mathrm{~m}$ thick. The lower $\mathrm{V}_{1}$ sub-unit may represent in whole 
or in part: (1) a facies change in the Qpc, (2) thin weathered Cooper Group Ashley Formation (Ta) or (3) weathered Parkers Ferry Formation (Tpc, Weems et al., 1997). The $V_{2}$ layer (792 $\mathrm{m} / \mathrm{s}$ ) is inferred to correlate with the Parkers Ferry Formation (upper Eocene) consisting of a dense calcilutite to very fine-grained calcarenite (Weems et al., 1997). $\mathrm{V}_{\mathrm{S} 30} \mathrm{NEHRP}$ soil profile type classification is "C" (very dense soil/soft rock).

\section{The Citadel, site 6}

High quality S-wave data to a depth of approximately $80 \mathrm{~m}$ was acquired at this site located just beyond the northeast boundary of The Citadel, Charleston, S.C. (Figure 1A). From the Swave column (Figure 7), we observed that the upper low-velocity $\mathrm{V}_{1}$ layer consists of a thin 1.5 $\mathrm{m}$ thick surficial unit of loose soil $(170 \mathrm{~m} / \mathrm{s})$ above the primary unit $(199 \mathrm{~m} / \mathrm{s})$ which is approximately $17 \mathrm{~m}$ thick. This layer overlies a $50 \mathrm{~m}$ thick $\mathrm{V}_{2}$ layer with a velocity of $492 \mathrm{~m} / \mathrm{s}$. A high amplitude reflection indicates a $V_{3}(795 \mathrm{~m} / \mathrm{s})$ layer starting at about $78 \mathrm{~m}$ depth.

Based upon information from auger hole sampling (Hadj-Hamou and Elton, 1989) and a projected geologic cross-section (Weems and Lemon (1993), a near-surface stratigraphy of approximately $17 \mathrm{~m}$ of predominantly loose to medium dense sand over Cooper Group formations is expected in the vicinity of our refraction/reflection profile. The expected contact depth matches closely with the $\mathrm{S}$-wave $\mathrm{V}_{1}$ layer thickness $(17 \mathrm{~m})$ determined by our survey. We correlate the $\mathrm{S}$-wave $\mathrm{V}_{1}$ layer with the upper barrier sand facies (Qws) and minor amounts of the lower clayey sand facies (Qwc) of Waldo Formation (Pleistocene, about 70-130 ka) (Weems and Lemon, 1993). The $\mathrm{S}$-wave $\mathrm{V}_{2}$ layer $(492 \mathrm{~m} / \mathrm{s})$ correlates with the Ashley Formation of the Cooper Croup (see Figure 1C). Based upon similarity in S-wave velocity, $795 \mathrm{~m} / \mathrm{s}$ for the USNSN site 9 and $792 \mathrm{~m} / \mathrm{s}$ for The Citadel V 3 layer (see S-wave profiles Figure 7), stratigraphic position, and personal communication (Weems, 2002), we interpret the deepest velocity layer at The Citadel site to correlate with the Parkers Ferry Formation. The $\mathrm{V}_{\mathrm{S} 30}$ NEHRP soil profile type classification is "C" (very dense soil/soft rock).

\section{Isle de Palm, site 8}

This site location is near the center of a barrier island approximately $16 \mathrm{~km}$ east of Charleston, S.C. (see Figure $1 A$ ). Both P- and S-wave velocity profiles show a distinct twolayer stratigraphy within the interpreted depth range of $30 \mathrm{~m}$ (Figure. 7). From the S-wave profile, the relatively thick $\mathrm{V}_{1}$ low velocity layer $(154 \mathrm{~m} / \mathrm{s})$ is interpreted to correlate with mapped Holocene beach and barrier island sands ((Qhs) Weems and Lemon, 1993). The S-wave $\mathrm{V}_{2}$ layer velocity $(497 \mathrm{~m} / \mathrm{s})$ is nearly identical to the $\mathrm{V}_{2}$ velocity determined at The Citadel site. Based on similarity in velocity, stratigraphic position and a geologic cross-section, this layer is correlated with the Cooper Group Ashley Formation. (Figures $1 C$ and 7). Although the $\mathrm{V}_{2}$ layer velocity at this site is relatively high, the influence of the $22 \mathrm{~m}$ thick $\mathrm{V}_{1}$ layer lowers the $\mathrm{V}_{\mathrm{S} 30}$ NEHRP soil profile type classification to "E" (soft soil).

\section{U.S. Hwy 17, site 7}

This site is located beneath an elevated bridge span of U.S. Highway 17 on the northeast side of the Ashley River (Figure $1 A$ ). Due to high levels of cultural noise and limited space, which prevented the acquisition of a far offset reverse profile, data quality is fair to poor (Figure 2). Three velocity layers are identified on the P-wave profile (Figure 7). It is believed that the unreasonably high $\mathrm{V}_{3}$ layer velocity of $2894 \mathrm{~m} / \mathrm{s}$, faster than any other P-wave velocity (except at the Lake Murray metamorphic rock site) determined at this site, results from an up-dipping interface related to the presence of an ancestral Ashley River channel margin (indicated in 
geologic cross-section, Weems and Lemon, 1993) which is now buried under the modern artificial fill. In this area, artificial filling operations began as early as 1680 and continued intermittently into the $20^{\text {th }}$ century in an effort to wrest more land from the sea (Mazyck, 1885; Hadj-Hamou and Elton, 1989).

The S-wave column shows two velocity layers (Figure 7). We interpret the approximately $11 \mathrm{~m}$ thick $\mathrm{V}_{1}$ layer $(125 \mathrm{~m} / \mathrm{s})$, the slowest $\mathrm{S}$-wave velocity determined during the study, to correlate with artificial fill. The calculated thickness of the $\mathrm{V}_{1}$ layer matches closely with mapped thickness of artificial fill for this location (Weems and Lemon, 1993). Geologic mapping (Weems and Lemon, 1993) indicates that in this area, which is outside of the modern river channel, the Cooper Group formations are overlain by facies of the Waldo Formation ((Qwc and Qws) Pleistocene, about 70-130 ka). Based upon the location of our survey with respect to a geologic cross-section, we tentatively correlate the $V_{2}$ layer at this site with the lower clayey sand facies (Qwc) of the Waldo Formation. Calculations using the interpreted $\mathrm{V}_{1}$ layer thickness of $11 \mathrm{~m}$ result in a $\mathrm{V}_{\mathrm{S} 30}$ value of $181 \mathrm{~m} / \mathrm{s}$; barely placing this site into a NEHRP soil profile type " $\mathrm{D}$ " classification (Tables 2 and 3). However, because a change of less then five percent $(5 \%)$ in $\mathrm{V}_{1}$ layer thickness (i.e. a change from 11 to $11.5 \mathrm{~m}$ ) would result in a NEHRP soil profile type "E" classification, we feel that it would be more realistic to initially view the mapped artificial fill sites as type "E" until more extensive site specific geophysical and engineering test data is acquired.

\section{CONCLUSION}

The P- and S-wave data acquired during this reconnaissance survey generally sampled increasingly younger geologic strata along a southeast-trending transect crossing the piedmont and Atlantic Coastal plain provinces of southeast South Carolina. Stratigraphic units tested range in age and composition from Paleozoic basement rocks of the Carolina Slate Group (metamorphosed sedimentary and volcanic rocks and intruded granites) to Holocene barrier island sands. Other than the Carolina Slate Group rocks (Lake Murray site), all sampled units sampled are sedimentary deposits.

Seismic refraction/reflection techniques produced S-wave data down to depths ranging from 30 to $80 \mathrm{~m}$ and identified in most cases two or three distinct velocity layers. Based upon reflection analysis, no "hidden" lower velocity layers beneath higher velocity layers were detected at these sites. At all sites (except the U.S. Highway 17 site where a substantial thickness of artificial fill is sampled), the upper most $\mathrm{V}_{1}$ layer is interpreted to represent weathered (developed soil horizons) and transitional strength lithologies. Collectively $\mathrm{V}_{1}$ layer thickness ranged from approximately 6.5 to $22 \mathrm{~m}$ and showed a velocity range of $125 \mathrm{~m} / \mathrm{s}$ (artificial fill) to $367 \mathrm{~m} / \mathrm{s}$ (upper Cretaceous Tuscaloosa Fm.). Excluding the Carolina Slate Group site (Lake Murray spillway), the overall average $\mathrm{S}$-wave $\mathrm{V}_{1}$ layer velocity is $225 \mathrm{~m} / \mathrm{s}$. For sites where the $\mathrm{V}_{1}$ layer thickness was greater than $12 \mathrm{~m}$, the $\mathrm{V}_{1}$ layer played a dominant role in determining the NEHRP soil profile type classification regardless of the underlying $\mathrm{V}_{2}$ layer velocity. This was especially evident at the Deep Creek site (Peedee Formation-upper Cretaceous) where a NEHRP classification of " $D$ " was determined even though the interpreted

$\mathrm{V}_{2}$ layer velocity was $710 \mathrm{~m} / \mathrm{s}$. For all other sites where a single formational unit was sampled (Figure. 6), NEHRP soil type classification was determined to be "C".

In general, at the four sites where multiple geologic formations were sampled (figure7) to a maximum depth of $80 \mathrm{~m}$, analysis shows an increase of $\mathrm{V}_{2}$ layer velocity with increase in 
formational age. Three of four sites sampled Cooper Group (Parkers Ferry and Ashley Formations, upper Eocene to middle Oligocene respectively) strata. Calculated NEHRP soil type classifications ranged from a strong " $\mathrm{C}$ " (very dense soil/soft rock) at the USNSN site to an " $\mathrm{E}$ " (soft soil) classification for the unconsolidated sand (Holocene) at the Isle de Palm. In general this range in classification values can be correlated directly to the stratigraphy at each individual site. The solid "C" classification at the USNSN site probably results from erosion having removed much of the softer overlying Ashley Formation. This results in a relatively thin $\mathrm{V}_{1}$ layer consisting of lower Pleistocene ((Tpc) clayey sand) and remnant Ashley Formation (?) resting upon higher-velocity Parkers Ferry Formation. At the Citadel site, the " $D$ " (stiff soil) classification results from the presence of an 18-m-thick $\mathrm{V}_{1}$ layer composed of unconsolidated to weakly lithified upper Pleistocene sands and clayey sands above the Ashley Formation.

Our results show that the non-invasive seismic-refraction/reflection method is an important tool in earthquake engineering. Information derived from the refraction/reflection data can be used to estimate site-response effects in the frequency range of ground motion that results in near-surface material destabilization and, ultimately, to building and infrastructure damage.

\section{ACKNOWLEDGMENTS}

We wish to thank Chuck Mueller for his comments and suggestions. The U. S. Nuclear Regulatory Commission (NRC) through a joint NRC/USGS interagency agreement provided funding for this project.

\section{APPENDIX-- Site descriptions of geologic units}

\section{Site 1: Murray Dam spillway}

Carolina Slate Group (Precambrian to Paleozoic)

Consists of metamorphosed sedimentary and volcanic rocks along with intruded granite masses (Overstreet and Bell, 1965).

\section{Site 2: Fort Jackson military base, Columbia S.C.}

Tuscaloosa Formation (middle to Upper Cretaceous) also known in some literature sources as the Middendorf Formation

In the near surface this formation is predominantly unconsolidated. The unit was deposited in a non-marine fluvial environment and consists of lenses and layers of sand to silty sand with interbeds of very pure clay (floodplain) and cross-bedded, channel fill sand (Pooser and Johnson, 1961).

\section{Site 3: Deep Creek School}

Peedee Formation (Upper Cretaceous)

At this site the formation consists of massive dark green to gray glauconitic sand interbedded with impure limestone. Deposition occurred predominantly in an open marine environment (Cooke, 1936).

Site 4: Black Mingo

Black Mingo Formation (Lower Eocene-Wilcox Group)

Partly indurated, fine-grained white to yellow sand and sugary sandstone and bioclastic limestone. Cementation is calcareous to siliceous. Upper units are underlain by gray to 
black laminated shale. Deposited under non-marine conditions in an estuarine, tidal flat and littorial low energy environment (Cooke, 1936).

\section{Site 5: Santee Limestone.}

Santee Limestone (Middle Eocene-Clayborne Group)

This unit is composed of alternating hard to soft layers of glauconitic impure to pure limestone and generally described in outcrop as consolidated but only weakly indurated. Hard ribs of limestone were exposed at the surface at the location where the refraction/reflection survey data was obtained. (Colquhoun and Duncan, 1967).

\section{Site 6: The Citadel}

Barrier sand facies (Quaternary) over Cooper Group (Ashley Formation, Oligocene $30 \mathrm{Ma}$ ) Upper two meters of site consists of modern fill and soil. These overlie upper barrier sand facies (Qws) and minor amounts of the lower clayey sand facies (Qwc) of Waldo Formation (Pleistocene, about 70-130 ka) Weems and Lemon (1993) which in turn unconformably overlie the Ashley Formation (upper unit of the Cooper Group). The Ashley Formation in this area is described as a fine-grained, massive, phosphatic calcarenite (Hadj-Hamou, 1989; Weems and Lemon, 1993).

The Cooper Group generally consists of soft impermeable limestone (locally called the Cooper Marl). The term "marl" refers to unconsolidated sands, shells, silts, and clays that are typically weakly consolidated with calcium carbonate. Units may be loose to dense in consistency. Within the study area the Cooper Group is represented by the Ashley and Parkers Ferry Formations and is known to underlie Holocene, Quaternary, and modern manmade fill within the Charleston S.C. area and large regions of the coastal plain in general (Cooke, 1936; Hadj-Hamou and Elton, 1989; Weems and Lemon, 1993).

\section{Site 7: Highway US 17 overpass next to Ashley River Memorial Bridge}

Modern fill over estuarine/lagoon facies, Waldo Formation? (70-130 ka)

Modern fill consists of dredged sand and clayey sand. Back barrier estuarine/lagoonmarsh deposits consisting of soft, organic rich clayey sand and clay (Weems and Lemon, 1993).

\section{Site 8: Isle of Palms}

Beach and barrier-island sand facies (Holocene $<1$ to $10 \mathrm{ka}$ ) over Cooper Group (Ashley Formation)

Loose, medium to dense fine-grained, well sorted quartz sand. Includes lenses and beds of clean to "muddy", fine-to medium-grained sand and medium to coarse shelly sand (shelf facies) in lower parts of some sections (McCartan et al, 1982; Weems and Lemon, 1993). For a description of barrier sand facies and the Ashley Formation see site 6 (Weems and Lemon, 1993).

\section{Site 9: USNSN}

Quaternary (Pleistocene $250 \mathrm{ka}$ to $1 \mathrm{Ma}$ ) over Cooper Group (thin Ashley (?) and Parkers Ferry Formations, upper Eocene to Oligocene)

This site lies within Pleistocene beach and barrier-island deposits that consist of fine to medium-grained, well-sorted, phosphatic quartz sand (Weems and Lemon, 1993). The 
Parkers Ferry Formation is a calcilutite to very fine-grained calcarenite that is very dense. For a detailed description of Cooper Group formations the reader is referred to Weems et al., 1997, and Weems and Lewis, 2002). Overburden map of Force (1978) and personal communication (Weems, 2002) indicated approximately $10 \mathrm{~m}$ of Quaternary strata over very thin Ashley over Parkers Ferry Formations at this site.

\section{REFERENCE CITED}

AAPG, 1989, Geological Highway Map Mid-Atlantic Region: published by the American Association of Petroleum Geologist

Bonini, W.E. and Woollard, G.P., 1960, Subsurface geology of North and South Carolina coastal plain from seismic data: American Association of Petroleum Geologists Bulletin, v. 44, no. 3, p. 298-315.

Borcherdt, R.D., Gibbs, J.F., and Fumal, T.E., 1979, Progress on ground motion predictions for the San Francisco Bay region, California: in Progress on Seismic Zonation in the San Francisco Bay Region, E. E. Brabb (Editor), U.S. Geological. Survey Circular 807, p. 13-25.

Building Seismic Safety Council, 1997, NEHRP recommended provisions for seismic regulations for new buildings: Part 1-Provisions (FEMA Federal Emergency Management Agency 302), 290 pp.

Campbell, K. W., and Duke, C. M., 1976, Correlations among seismic velocity, depth and geology in the Los Angeles area: School of Engineering and Applied Science, UCLS, UCLA-ENG-7662

Colquhoun, D.J. and Duncan, D.A., 1967, Geology of the Eutawville quadrangle, South Carolina: MS-12, scale 1:62,500, Division of Geology, South Carolina State Development Board

Cooke, C.W., 1936, Geology of the coastal plain of South Carolina: U.S. Geological Survey Bulletin 867, p. 196.

Dutton, C.E., 1889, The Charleston earthquake of August 31, 1886, in Ninth Annual Report of the Director, 1887-1888: U.S. Geological Survey, Denver, CO, p. 203-528.

Force, L., M., 1978, Geological studies of the Charleston, South Carolina, area-thickness of overburden map: U.S. Geological Survey Miscellaneous Field Studies Map MF-1021 B, Scale 1:250,000. 
Hadj-Hamou, Tarik and Elton, D.J., 1989, A liquefaction susceptibility map for peninsular Charleston, South Carolina: Association of Engineering Geology Bulletin, v. 26, no. 3, p. 309-333.

Harris, J., Street, R., Kiefer, D., Allen, D., and Wang, Z., 1994, Modeling site response in the Paducah, Kentucky, area: Earthquake Spectra, v. 10, p.519-538.

Joyner, W.B., Warrick, R.E., and Fumal, T.E., 1981, The effect of Quaternary alluvium on strong ground motion in the Coyote Lake, California earthquake of 1979: Seismological Society of America Bulletin, v.71, p. 1333-1349.

Mazyck, A., 1885, Charleston in 1885: Walker, Evans, and Cogswell, Charleston, S. C., 95 pp.

McCartan, Lucy, Lemon, E.M. Jr., Weems, R.E., 1982, Generalized geologic map of the Charleston, South Carolina, area: U.S. Geological Survey Open-File Report 82-187, scale 1:575,000.

Mooney, H. M., 1984, Handbook of Geophysical Exploration, Volume 1, Seismic, Bison Instruments, Inc.

Mueller, Charles, 2000, Site response in the Atlantic and Gulf of Mexico Coastal Plains and Mississippi Embayment: Proceedings of the Sixth International Conference on Seismic Zonation, November 12-15, 2000, Palm Springs, CA, Earthquake Engineering Research Institute CD-Rom

Overstreet, W.C. and Bell, Henry III, 1965, The crystalline rocks of South Carolina: U.S. Geological Survey Bulletin 1183, p.126.

Paradesse, W., McCauley, J.F., and Colquhoun, D.J., 1953, The geology of the Blythwood quadrangle, South Carolina: Division of Geology, State Development Board, South Carolina, Map MS-13, Scale1:24,000.

Pooser, W.K. and Johnson, H.S., 1961, Geology of the Fort Jackson north quadrangle, South Carolina: Division of Geology, South Carolina. State Development Board, Map MS-3, Scale $1: 24,000$.

Seed, H.B., Romo, M.P., Sun, J.I., Jaime, A., Lysmer, J., 1988, The Mexico earthquake of September 19, 1985-relationships between soil conditions and earthquake ground motions: Earthquake Spectra, v. 4, p. 687-729.

Weems,, R.E., and Lemon, E. M. Jr., 1993, Geology of the Cainhoy, Charleston, Fort Moultrie, and North Charleston Quadrangles, Charleston and Berkeley Counties: South Carolina: U.S. Geological Survey Map I-1935, Scale 1:24,000 
Weems, R.E., Lemon, E.M, and Nelson, M.S., 1997, Geology of the Pringletown, Ridgeville, Summervill. and Summerville Northwest 7.5-minute quadrangles, Berkeley, Charleston, and Dorchester Counties, South Carolina: U. S. Geological Survey Miscellaneous Investigations Series Map-I 2502, Scale 1:24,000.

Weems, R.E. and Lewis, C.W., 2002, Structural and tectonic setting of the Charleston, South Carolina, region, evidence from the Tertiary stratigraphic record: Geological Society of America Bulletin, v 114, no. 1, p. 24-42.

Wheeler, R.L. and Cramer, C.H., 2000, Preliminary estimate of the amplification of possible earthquake ground motion at a site in Charleston County, South Carolina: U.S. Geological Survey Open-File Report 00-0484, 32 p.

Williams, R. A., Cranswick, E., King, K. W., Carver, D. L., and Worley, D.M., 1994, Siteresponse models from high-resolution seismic reflection and refraction data recorded in Santa Cruz, California: in The Loma Prieta, California, Earthquake of October 17, 1989Strong Ground Motion, R. G. Borcherdt, (Editor), U.S. Geological Survey Professional Paper 1551-A, A217-242.

Williams, R.A., Stephenson, W.J. and Odum, J.K., 1998, Surface-seismic imaging for NEHRP soil profile classifications and earthquake hazards in urban areas: Geotechnical Special Publication No. 75: Geotechnical Earthquake Engineering and Soil Dynamics III, v. 1, Dakoulas, P., Yegian, M., and Holz, R. D., (Editors), American Society of Civil Engineers, Proceedings of a Specialty Conference, Seattle, WA. p. 166-177.

Williams, R.A., Stephenson, W.J, Frankel, A.D. and Odum, J.K., 1999, Surface seismic measurements of near-surface P-and S-wave seismic velocities at earthquake recording stations, Seattle, Washington: Earthquake Spectra, v. 15, no. 3, p. 565-584.

Woolery, E., Street, R., Wang, Z., and J. Harris, 2000, NEHRP soil classifications and 1-D site effects in the upper Mississippi Embayment, Seismological Research Letters, v. 71, no. 1, p. 114. 